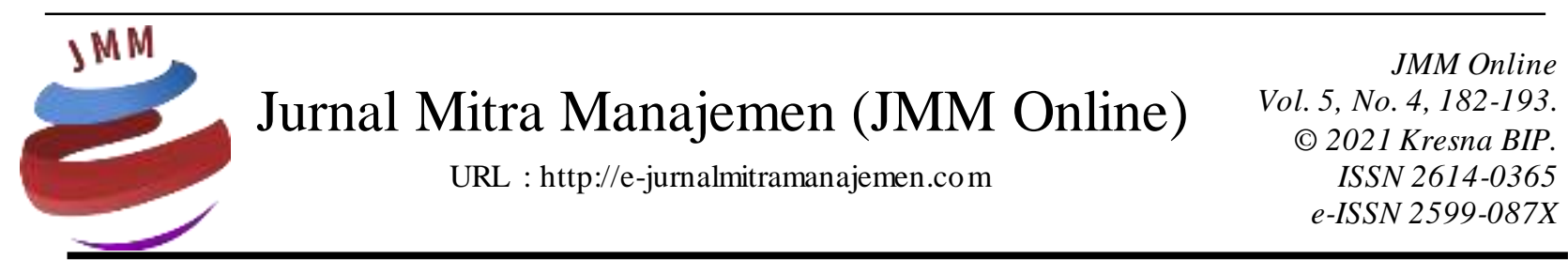

\title{
PENGARUH DISIPLIN KERJA, ETOS KERJA, DAN PELATIHAN TERHADAP KINERJA KARYAWAN DI PT. BRATACO CABANG SURABAYA
}

\author{
Satrya Yudha Arrizky 1), Wasis Budiarto ${ }^{2)}$, Indra Prasetyo ${ }^{3)}$ \\ Universitas Wijaya Putra Surabaya
}

INFORMASI ARTIKEL

Dikirim : 31 Maret 2021

Revisi pertama : 05 April 2021

Diterima :09 April 2021

Tersedia online : 06 Mei 2021

Kata Kunci: Disiplin Kerja, Etos Kerja, Pelatihan, Kinerja Karyawan

Email : satryaffua@gmail.com

\section{ABSTRAK}

Penelitian ini bertujuan untuk mengetahui pengaruh disiplin kerja, etos kerja, pelatihan terhadap kinerja karyawan di PT. Brataco Cabang Surabaya. Penelitian ini termasuk penelitian kuantitatif. Sampel diambil dengan menggunakan teknik nonprobability sampling berjumlah 49 responden. Data yang digunakan dalam penelitian ini adalah data primer dari karyawan PT. Brataco Cabang Surabaya dan data sekunder yaitu data absensi karyawan PT. Brataco Cabang Surabaya. Teknik analisis menggunakan regresi linier berganda. Berdasarkan hasil penelitian yang telah dilakukan didapatkan hasil bahwa Karyawan di PT. Brataco Cabang Surabaya memiliki disiplin kerja, etos kerja, pelatihan, dan kinerja yang tinggi. Disiplin kerja berpengaruh terhadap kinerja karyawan di PT. Brataco Cabang Surabaya. Etos kerja berpengaruh terhadap kinerja karyawan di PT. Brataco Cabang Surabaya. Pelatihan berpengaruh terhadap kinerja karyawan di PT. Brataco Cabang Surabaya. 


\section{PENDAHULUAN \\ Latar Belakang}

PT Brataco merupakan Importir dan Supplier Bahan Baku Kimia untuk farmasi, kosmetik, industri teknik, industri rumah tangga, water treatment, industri makanan dan minuman serta bakery. Sektor industri, menyediakan Acid Gebberilic, Aqua DM, Disinfectan C/L, Phospaste products, Activated Carbon, Water treatment chemicals, PAC powder, TCCA, Boiler, Cooling tower chemicals, Kaporit $60 \%$ dan $70 \%$ serta Maltex. Sama halnya dengan perusahaan lain, dalam meningkatkan kualitas hasil atau keberhasilan perusahaan harus memiliki karyawan yang memiliki kinerja yang tinggi. Namun saat ini, pada PT Brataco cabang Surabaya masih ditemukan adanya karyawan yang memiliki kinerja yang kurang. Hal ini tentunya akan berdampak pada performa perusahaan.

Setiap perusahaan akan selalu berusaha untuk meningkatkan kinerja karyawannya, dengan harapan apa yang menjadi tujuan perusahaan akan tercapai, tak terkecuali pada PT. Brataco Cabang Surabaya. Kemampuan karyawan tercermin dari kinerja, kinerja yang baik adalah kinerja yang optimal. Kinerja karyawan tersebut merupakan salah satu modal bagi perusahaan untuk mencapai tujuannya. Sehingga kinerja karyawan adalah hal yang patut diperhatikan oleh pemimpin perusahaan.

Kinerja pada umumnya diartikan sebagai kesuksesan seseorang dalam melaksanakan suatu pekerjaan. Kinerja karyawan merupakan hasil kerja yang dicapai seseorang dalam melaksanakan tugas-tugas yang dibebankan kepadanya untuk mencapai target kerja. Karyawan dapat bekerja dengan baik bila memiliki kinerja yang tinggi sehingga dapat menghasilkan kerja yang baik. Kinerja karyawan merupakan salah satu faktor penentu keberhasilan perusahaan atau organisasi dalam mencapai tujuannya. Untuk itu kinerja dari para karyawan harus mendapat perhatian dari para pimpinan perusahaan, sebab menurunnya kinerja dari karyawan dapat mempengaruhi kinerja perusahaan secara keseluruhan.

Faktor-faktor yang mempengaruhi kinerja karyawan, penting sekali untuk diperhatikan karena merupakan salah satu cara untuk meningkatkan kualitas sumberdaya manusia (karyawan). Anoraga (2014) menjelaskan faktor-faktor yang mempengaruhi kinerja adalah motivasi, pelatihan dan pendidikan, kompensasi, teknologi, ketrampilan dan disiplin kerja. Salah satu instrumen dalam pengembangan dan kualitas sumber daya manusia - para karyawan adalah melalui pendidikan, pelatihan, dan kursus-kursus yang masih menjadi tantangan dan kendala untuk merubah kinerja karyawannya. Pengembangan karyawan melalui pelatihan bisa memantapkan kinerja karyawan, meningkatkan pengetahuan, keahlian dan ketrampilan untuk membentuk sedini mungkin kepribadian pegawai yang profesionalisme.

Menurut Sinamo (2011) etos kerja adalah seperangkat perilaku kerja positif yang berakar pada kerjasama yang kental, keyakinan yang fundamental, disertai komitmen yang total pada paradigma kerja yang integral. Etos kerja merupakan sikap yang mendasar terhadap diri yang membentuk perilaku kerja positif yang berakar pada kesadaran mental, keyakinan yang fundamental, disertai komitmen yang total pada paradigma kerja yang integral. Apabila dikaitkan dengan situasi kehidupan manusia yang sedang membangun, maka etos kerja yang tinggi akan dijadikan sebagai persyaratan yang mutlak, yang ditumbuhkan dalam kehidupan. 
Selain etos kerja, disiplin kerja juga menjadi hal penting dalam meningkatkan kinerja pegawai. Menurut Hasibuan (2017:20), faktor disiplin sangat berpengaruh terhadap kinerja pegawai. Disiplin biasanya berbanding lurus terhadap kinerja pegawai dalam suatu perusahaan, bila tingkat disiplin kerja pegawai baik, maka tingkat kinerja pegawai juga akan baik. Menurut Hasibuan (2017), kedisplinan merupakan fungsi Manajemen Sumber Daya Manusia (MSDM) yang terpenting dan kunci terwujudnya tujuan karena tanpa disiplin yang baik sulit terwujud tujuan yang maksimal. Seorang karyawan dikatakan memiliki disiplin kerja yang tinggi apabila memenuhi kriteria berdasarkan sikap, norma dan tanggung jawab. Kriteria berdasarkan sikap mengacu pada mental dan perilaku karyawan yang berasal dari kesadaran atau kerelaan dirinya sendiri dalam melaksanakan tugas dan peraturan perusahaaan. Kriteria berdasarkan norma terkait peraturan tentang apa yang boleh dan apa yang tidak boleh dilakukan oleh para karyawan selama dalam perusahaan. Kriteria berdasarkan tanggung jawab merupakan kemampuan dalam menjalankan tugas dan peraturan dalam perusahaan.

Dessler (2015) mengungkapkan bahwa pelatihan adalah serangkaian aktivitas yang drancang untuk mengajarkan ketrampilan yang dibutuhkan karyawan baru maupun yang ada sekarang, ketrampilan dasar yang mereka butuhkan untuk menjalankan pekerjaan mereka. Karyawan lama juga perlu belajar dan dilatih dengan tujuan untuk memperbaiki kinerja yang kurang baik, mempelajari pengetahuan dan teknologi serta ketrampilan yang baru, juga untuk menyesuaikan dengan perkembangan organisasi dan kebijakan organisasi yang baru Pelatihan selain bertujuan untuk mengurangi suatu masalah perusahaan, juga dimaksudkan untuk memperoleh nilai tambah bagi tenaga kerja yang bersangkutan. Kegiatan pelatihan merupakan suatu proses aplikasi, yang dalam kegiatan pelaksanaanya membutuhkan suatu perencanaan yang matang sehingga dapat menghasilkan kinerja yang maksimal.

Pelatihan merupakan cara yang paling efektif bagi perusahaan yang ingin menjadikan sumber daya manusianya sebagai keunggulan yang kompetitif Kegiatan atau pelaskanaan pelatihan akan dapat mengembangkan kemampuan pegawai atau karyawan dalam menangani pekerjaan mereka pada saat itu tetapi juga bisa melakukan pekerjaan-pekerjaan yang sesuai dengan kemampuannya di masa mendatang. Pelatihan pada dasarnya merupakan cara yang penting untuk meningkatkan kualitas pekerjaan yang dilakukan di dalam instansi.

Berdasarkan uraian permasalahan diatas untuk mengetahui pengaruh disiplin kerja, etos kerja, dan pelatihan terhadap kinerja, maka penulis mengambil judul penelitian "Pengaruh Disiplin Kerja, Etos Kerja, dan Pelatihan Terhadap Kinerja karyawan di PT. Brataco Cabang Surabaya".

\section{Rumusan Masalah}

Berdasarkan uraian latar belakang tersebut, maka rumusan masalah dalam penelitian ini antara lain:

1. Bagaimana disiplin kerja, etos kerja, pelatihan, dan kinerja karyawan di PT. Brataco Cabang Surabaya?

2. Apakah disiplin kerja berpengaruh secara parsial terhadap kinerja karyawan di PT. Brataco Cabang Surabaya? 
3. Apakah etos kerja berpengaruh secara parsial terhadap kinerja karyawan di PT. Brataco Cabang Surabaya?

4. Apakah pelatihan berpengaruh secara parsial terhadap kinerja karyawan di PT. Brataco Cabang Surabaya?

\section{Tujuan Penelitian}

Tujuan penelitian untuk menjawab rumusan masalah adalah sebagai berikut:

1. Menguji disiplin kerja, etos kerja, pelatihan, dan kinerja karyawan di PT. Brataco Cabang Surabaya.

2. Menguji pengaruh disiplin kerja terhadap kinerja karyawan di PT. Brataco Cabang Surabaya.

3. Menguji pengaruh etos kerja, terhadap kinerja karyawan di PT. Brataco Cabang Surabaya.

4. Menguji pengaruh pelatihan secara parsial terhadap kinerja karyawan di PT. Brataco Cabang Surabaya.

\section{KAJIAN PUSTAKA}

\section{Kinerja}

Menurut Mangkunegara (2015), kinerja pegawai adalah hasil kerja secara kualitas dan kuantitas yang dicapai oleh seorang pegawai dalam melaksanakan tugasnya sesuai dengan tanggung jawab yang diberikan kepadanya. Sedangkan menurut Hasibuan (2017) kinerja adalah suatu hasil kerja yang dicapai seseorang dalam melaksanakan tugas-tugas yang dibebankan kepadanya yang didasarkan atas kecakapan, pengalaman dan kesungguhan serta waktu. Menurut Setiawan dan Kartika (2014) untuk mengukur kinerja dapat menggunakan indikator-indikator sebagai berikut:

1. Ketepatan penyelesaian tugas merupakan pengelolaan waktu dalam bekerja dan juga ketepatan pegawai dalam menyelesaikan pekerjaan

2. Kesesuaian jam kerja merupakan kesediaan pegawai dalam mematuhi peraturan perusahaan yang berkaitan dengan ketepatan waktu masuk/pulang kerja dan jumlah kehadiran

3. Tingkat kehadiran dapat dilihat dari jumlah ketidakhadiran pegawai dalam suatu perusahaan selama periode tertentu.

4. Kerjasama antar pegawai merupakan kemampuan pegawai untuk bekerja sama dengan orang lain dalam menyelesaikan suatu tugas yang ditentukan sehingga mencapai daya guna dan hasil guna yang sebesar-besarnya.

\section{Disiplin Kerja}

Menurut Simamora (2015) disiplin adalah prosedur yang mengoreksi atau menghukum bawahan karena melanggar peraturan atau prosedur. Disiplin kerja adalah suatu alat yang digunakan para manajer untuk berkomunikasi dengan karyawan agar mereka bersedia untuk mengubah suatu perilaku serta sebagai suatu upaya untuk meningkatkan kesadaran dan kesediaan seseorang menaati semua peraturan perusahaan dan norma-norma sosial yang berlaku (Rivai, 2015). Menurut Hasibuan (2017) indikator disiplin kerja yaitu: 
1. Sikap Mental dan perilaku karyawan yang berasal dari kesadaran atau kerelaan dirinya sendiri dlam melaksanakan tugas dan peraturan perusahaaan, terdiri dari: a) Kehadiran berkaitan dengan keberadaan karyawan ditempat kerja untuk bekerja b) Mampu memanfaatkan dan menggunakan perlengkapan dengan baik

2. Norma Peraturan tentang apa yang boleh dan apa yang tidak boleh dilakukan oleh para karyawan selama dalam peruahaan dan sebagai acuan dalam bersikap, terdiri dari: a) Mematuhi peraturan merupakan karyawan secara sadar mematuhi peraturan yang ditentukan perusahaan. b) Mengikuti cara kerja yang ditentukan perusahaan

3. Tanggung jawab Merupakan kemampuan dalam menjalankan tugas dan peraturan dalam perusahaan. Menyelesaikan pekerjaan pada waktu yang ditentukan karyawan harus bertanggung jawab atas pekerjaannya dengan menyelesaikan pekerjaan tepat pada waktu yang ditentukan perusahaan.

\section{Etos Kerja}

Etos kerja seseorang erat kaitannya dengan kepribadian, perilaku dan karakter. Setiap orang memiliki internal being yang merupakan siapa dia. Kemudian intenal being menetapkan respon atau reaksi terhadap tuntutan eksternal. Respon internal being terhadap tuntutan eksternal dunia kerja menetapkan etos kerja seseorang (Siregar, 2000). Etos berasal dari bahasa yunani ethos yakni karakter, cara hidup, kebiasaan seseorang, motivasi atau tujuan moral seseorang serta pandangan dunia mereka, yakni gambaran, cara bertindak ataupun gagasan yang paling komprehensif mengenai tatanan. Dengan kata lain etos adalah aspek evaluatif sebagai sikap mendasar terhadap diri dan dunia mereka yang direfleksikan dalam kehidupannya (Khasanah, 2004).

\section{Pelatihan}

Menurut Dessler (2015) pengertian pelatihan adalah proses mengajar keterampilan yang dibutuhkan karyawan untuk melakukan pekerjaannya. Pelatihan mengacu pada metode yang digunakan untuk memberikan karyawan baru atau yang ada saat ini dengan keterampilan yang mereka butuhkan saat ini dengan keterampilan yang mereka butuhkan untuk melakukan pekerjaan. Sedangkan menurut Simanjuntak (2011) mendefinisikan pelatihan merupakan bagian dari investasi SDM (human investment) untuk meningkatkan kemampuan dan keterampilan kerja, dan dengan demikian meningkatkan kinerja pegawai. Pelatihan biasanya dilakukan dengan kurikulum yang disesuaikan dengan kebutuhan jabatan, diberikan dalam waktu yang relatif pendek, untuk membekali seseorang dengan keterampilan kerja.

\section{METODE PENELITIAN}

\section{Jenis dan Pendekatan Penelitian}

Penelitian ini menggunakan pendekatan kuantitatif, karena penelitian ini disajikan dengan angka-angka. Hal ini sesuai dengan pendapat (Arikunto, 2016) yang mengemukakan penelitian kuantitatif adalah pendekatan penelitian yang banyak dituntut menguakan angka, mulai dari pengumpulan data, penafsiran terhadap data tersebut, serta penampilan hasilnya. Penelitian ini merupakan katagori crosssectional, yaitu informasi dari sebagian populasi (sampel responden) dikumpulkan langsung dari 
lokasi secara empirik dengan tujuan untuk mengetahui pendapat dari sebagian populasi terhadap objek yang diteliti.

\section{Lokasi dan Subyek Penelitian}

Lokasi penelitian dilakukan di PT. Brataco Cabang Surabaya. Populasi dalam penelitian ini adalah seluruh karyawan PT. Brataco Cabang Surabaya sebanyak 49 orang. Pada penelitian ini menggunakan sampel sebanyak 49 responden dengan teknik nonprobability sampling.

\section{Teknik Pengumpulan Data}

sekunder.

Data yang digunakan dalam penelitian ini adalah data primer dan data

\section{Data Primer}

Data yang digunakan dalam penelitian ini adalah data primer, yaitu data penelitian yang diambil langsung dari karyawan PT. Brataco Cabang Surabaya. Metode pengumpulan data primer yang digunakan dalam penelitian ini yaitu dengan menggunakan kuesioner. Kuesioner yang diberikan merupakan lembaran pertanyaan yang mengukur variabel disiplin kerja, etos kerja, dan pelatihan pada masing-masing responden.

2. Data Sekunder

Data sekunder yang digunakan dalam penelitian ini adalah data absensi karyawan PT. Brataco Cabang Surabaya.

\section{Teknik Analisis Data}

berikut:

Metode analisis data yang akan digunakan dalam penelitian ini adalah sebagai

1. Uji Validitas dan Reliabilitas Instrumen

Validitas adalah suatu ukuran yang menunjukkan tingkat ketepatan suatu alat ukur. Analisis yang digunakan untuk pengujian validitas kuesioner adalah uji korelasi product moment (Sugiyono, 2017).

Reliabilitas adalah uji yang bertujuan untuk mengetahui seberapa jauh alat ukur dalam hal ini kuesioner dapat dihandalkan atau dipercaya. Pengujian reliabilitas kuesioner dapat dilakukan dengan uji Cronbach's Alpha.

2. Uji Asumsi Klasik

Uji asumsi klasik yaitu persyaratan yang harus dipenuhi pada analisis regresi linier berganda yang berbasis Ordinary Least Square (OLS). Uji asumsi dalam regresi linier berganda antara lain uji normalitas, uji multikolinearitas, uji heteroskedastisitas, dan uji autokorelasi.

3. Analisis Regresi Linier Berganda

Variabel independen dalam penelitian ini adalah disiplin kerja $\left(\mathrm{X}_{1}\right)$, etos kerja $\left(\mathrm{X}_{2}\right)$, dan pelatihan $\left(\mathrm{X}_{3}\right)$. Sedangkan variabel dependen adalah kinerja $(\mathrm{Y})$. Model regresi berganda yang dikembangkan pada penelitian ini dinotasikan dalam persamaan sebagai berikut:

$$
Y=\beta_{0}+\beta_{1} X_{1}+\beta_{2} X_{2}+\beta_{3} X_{3}+\varepsilon
$$




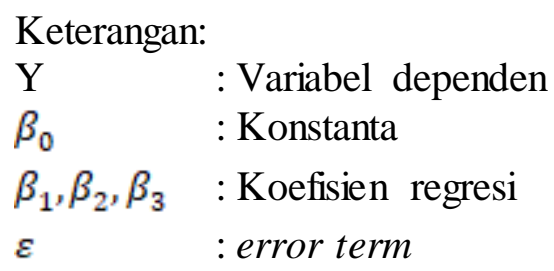

a. Uji Parsial (Uji t)

Uji parsial (uji t) digunakan untuk menguji variabel-variabel independen yang berpengaruh terhadap variabel dependen secara parsial.

\section{HASIL PENELITIAN DAN PEMBAHASAN \\ Hasil Penelitian}

Deskripsi Variabel Penelitian

\section{Disiplin Kerja}

Rata-rata variable disiplin kerja sebesar 4.35. Hal ini menunjukkan bahwa disiplin kerja pegawai PT. Brataco Cabang Surabaya termasuk dalam kategori tinggi.

2. Etos Kerja

Rata-rata variable etos kerja sebesar 4.37. Hal ini menunjukkan bahwa etos kerja pegawai PT. Brataco Cabang Surabaya termasuk dalam kategori tinggi.

3. Pelatihan

Rata-rata pada variable pelatihan diketahui sebesar 4,39 yang termasuk dalam kategori tinggi.

4. Kinerja

Rata-rata variable kinerja sebesar 4,32 yang menunjukkan bahwa kinerja yang dihasilkan pegawai PT. Brataco Cabang Surabaya termasuk dalam kategori tinggi.

\section{Uji Parsial (Uji t)}

Uji t digunakan untuk menguji koefisien regresi secara parsial dari variabel independennya, apakah masing-masing disiplin kerja, etos kerja, dan pelatihan berpengaruh terhadap kinerja pegawai. Kriteria keputusan yaitu dengan melihat nilai signifikansi masing-masing variabel yang akan dibandingkan nilai derajat kesalahan sebesar $5 \%$.

Tabel 1. Uji Parsial

\begin{tabular}{cccc}
\hline Variabel & Koefisien & $t$ & $\boldsymbol{P}$ \\
\hline Konstanta & $-0,183$ & $-0,444$ & 0,659 \\
\hline Disiplin Kerja $\left(\mathrm{X}_{1}\right)$ & 0,470 & 4,995 & 0,000 \\
\hline Etos Kerja $\left(\mathrm{X}_{2}\right)$ & 0,324 & 3,143 & 0,003 \\
\hline Pelatihan $\left(\mathrm{X}_{3}\right)$ & 0,237 & 2,254 & 0,029 \\
\hline
\end{tabular}

Sumber : Hasil Output SPSS 23

Model regresi yang terbentuk berdasarkan hasil analisis adalah sebagai berikut:

$$
y=-0,183+0,470 X_{1}+0,324 X_{2}+0,237 X_{3}
$$

Nilai koefisien pengaruh disiplin kerja terhadap kinerja pegawai PT. Brataco Cabang Surabaya sebesar 0,470. Hal ini menunjukkan bahwa disiplin kerja berpengaruh secara positif terhadap kinerja. Apabila rata-rata disiplin kerja pegawai 
naik sebesar 1, maka kinerja pegawai akan naik sebesar 0,470. Nilai signifikansi yang diperoleh pada variable disiplin kerja sebesar $0,000 \quad(p<0,05)$. Sehingga dapat disimpulkan bahwa disiplin kerja berpengaruh signifikan terhadap kinerja pegawai PT. Brataco Cabang Surabaya.

Pada variable etos kerja, didapatkan nilai koefisien sebesar 0,324 yang berarti etos kerja memiliki pengaruh yang positif terhadap kinerja. Semakin naik nilai etos kerja maka kinerja pegawai juga akan semakin naik. Nilai signifikansi yang didapatkan pada variable etos kerja adalah sebesar $0,003(\mathrm{p}<0,05)$ yang berarti bahwa etos kerja berpengaruh signifikan terhadap kinerja pegawai PT. Brataco Cabang Surabaya.

Kemudian pada variable pelatihan, didapatkan nilai koefisien sebesar 0,237 yang berarti bahwa apabila rata-rata variable pelatihan naik sebesar 1, maka kinerja pegawai yang dihasilkan akan naik sebesar 0,237. Selain itu nilai signifikansi yang diperoleh sebsar 0,029 $(\mathrm{p}<0,05)$ yang berarti bahwa pelatihan berpengaruh signifikan terhadap kinerja pegawai PT. Brataco Cabang Surabaya.

\section{Koefisien Determinasi}

Koefisien determinasi $\left(\mathrm{R}^{2}\right)$ digunakan untuk mengukur seberapa jauh kemampuan model dalam menjelaskan variasi variabel dependen. Dalam penelitian ini koefisien determinasi menggunakan nilai adjusted $\mathrm{R}^{2}$.

Tabel 2. Koefisien Determinasi Variabel Kinerja

\begin{tabular}{ccc}
\hline $\mathbf{R}$ & R Square & Adjusted R Square \\
\hline 0,867 & 0,751 & 0,734
\end{tabular}

Dari hasil koefisien determinasi, diperoleh nilai adjusted $\mathrm{R}^{2}$ sebesar 0,734 atau 73,4\%. Hal ini menunjukkan bahwa kinerja pegawai PT. Brataco Cabang Surabaya dapat dijelaskan sebesar 73,4\% oleh variabel independen yaitu disiplin kerja, etos kerja, dan pelatihan. Sedangkan 26,6\% variasi kinerja PT. Brataco Cabang Surabaya dijelaskan oleh variabel-variabel diluar variabel independen penelitian ini.

\section{Pembahasan}

\section{Pengaruh Disiplin Kerja terhadap Kinerja Pegawai}

Hasil analisis menunjukkan bahwa nlai koefisien pengaruh disiplin kerja terhadap kinerja pegawai PT. Brataco Cabang Surabaya sebesar 0,470. Hal ini menunjukkan bahwa disiplin kerja berpengaruh secara positif terhadap kinerja. Apabila rata-rata disiplin kerja pegawai naik sebesar 1, maka kinerja pegawai akan naik sebesar 0,470. Nilai signifikansi yang diperoleh pada variable disiplin kerja sebesar 0,000 $(\mathrm{p}<0,05)$. Sehingga dapat disimpulkan bahwa disiplin kerja berpengaruh signifikan terhadap kinerja pegawai PT. Brataco Cabang Surabaya.

Salah satu faktor yang mempengaruhi kinerja karyawan adalah disiplin kerja. Menurut Simamora (2015) disiplin adalah prosedur yang mengoreksi atau menghukum bawahan karena melanggar peraturan atau prosedur. Disiplin kerja adalah suatu alat yang digunakan para manajer untukberkomunikasi dengan karyawan agar mereka bersedia untuk mengubah suatu perilaku serta sebagai suatu upaya untuk meningkatkan kesadaran dan kesediaan seseorang menaati semua peraturan perusahaan dan norma-norma sosial yang berlaku (Rivai, 2015). 
Disiplin kerja dipengaruhi oleh dapat dipengaruhi oleh semangat kerja karyawan, tingkat kompensasi yang diberikan, serta kepuasan kerja karyawan. Dimana karyawan dengan semangat kerja yang tinggi cenderung akan bekerja dengan lebih baik, tepat waktu, dan tidak pernah membolos. Karyawan akan semangat untuk berangkat kerja sehingga disiplin kerja nya menjadi tinggi. Dengan dilandasi dengan aspek aspek di atas maka kedisplinan kerja akan berpengaruh besar pada kinerja perusahaan. Ketika tingkat disiplin kerja suatu perusahaan itu tinggi maka diharapkan karyawan akan bekerja lebih baik, sehingga produktivitas perusahaan meningkat. Selain itu disiplin kerja yang baik akan meningkatkan efisiensi kerja semaksimal mungkin, tidak menghabiskan waktu yang banyak bagi perusahaan untuk sekedar melakukan pembenahan diaspek kedisplinan tersebut dan waktu dapat digunakan untuk mencapai tujuan perusahaan.

Pengaruh disiplin kerja terhadap kinerja karyawan telah dikemukakan dalam penelitian Ariana (2013). Dalam penelitiannya disebutkan bahwa perusahaan bisa lebih memperhatikan kemampuan karyawan, balas jasa terhadap karyawan, sanksi terhadap pelanggaran disiplin, pengawasan yang lebih ketat dalam upaya meningkatkan atau memperbaiki kinerja karyawan. Hal-hal tersebut membuktikan bahwa disiplin kerja merupakan faktor penting dalam meningkatkan kinerja karyawan. Dengan adanya disiplin kerja yang baik dari karyawan seperti datang tepat waktu, melaksanakan pekerjaan sesuai dengan apa yang telah ditetapkan oleh perusahaan, mentaati peraturan perusahaan maka akan dapat meningkatkan kinerja dari karyawan tersebut sehingga target perusahaan akan tercapai.

Penelitian ini relevan dengan penelitian yang dilakukan oleh Ariana (2013) yang melakukan penelitian tentang pengaruh kepemimpinan, kompensasi, dan disiplin kerja terhadap kinerja karyawan pada Hotel Cendana Resort dan Spa Ubud, Gianyar Bali. Hasil penelitian ini menunjukkan bahwa variabel disiplin kerja mempengaruhi kinerja karyawan.

\section{Pengaruh Etos Kerja terhadap Kinerja Pegawai}

Hasil penelitian ini, pada variable etos kerja didapatkan nilai koefisien sebesar 0,324 yang berarti etos kerja memiliki pengaruh yang positif terhadap kinerja. Semakin naik nilai etos kerja maka kinerja pegawai juga akan semakin naik. Nilai signifikansi yang didapatkan pada variable etos kerja adalah sebesar $0,003(\mathrm{p}<0,05)$ yang berarti bahwa etos kerja berpengaruh signifikan terhadap kinerja pegawai PT. Brataco Cabang Surabaya.

Hasil penelitian ini menunjukkan hasil yang sama dengan penelitian sebelumnya yang dilakukan oleh Saleha (2016) tentang "Pengaruh Lingkungan Kerja, Etos Kerja dan Budaya Kerja terhadap Kinerja Pegawai pada Dinas Bina Marga Propinsi Sulawesi Tengah". Hasil penelitian menunjukkan bahwa etos kerja berpengaruh signifikan terhadap kinerja pegawai Dinas Bina Marga Propinsi Sulawesi Tengah

Faktor pertama yang mempengaruhi kinerja karyawan adalah etos kerja. Etos adalah aspek evaluatif sebagai sikap mendasar terhadap diri dan dunia mereka yang direfleksikan dalam kehidupannya (Khasanah, 2004:8). Etos kerja yang tinggi seyogyanya dimiliki setiap pegawai atau pemimpin di suatu lembaga, ini sangat membutuhkan kerja keras dan komitmen yang tinggi dari setiap pegawai, kalau tidak 
organisasi akan sulit berkembang, dan memenangkan persaingan dalam merebut pangsa pasarnya. Tasmara, (2002) menjabarkan etos kerja yang seharusnya dimiliki oleh seorang pegawai adalah totalitas kepribadian dirinya serta caranya mengekspresikan, memandang, meyakini dan memberikan makna ada sesuatu, yang mendorong dirinya untuk bertindak dan meraih amal yang optimal sehingga pola hubungan antara manusia dengan dirinya dan antara manusia dengan makhluk lainnya dapat terjalin dengan baik.

\section{Pengaruh Pelatihan terhadap Kinerja Pegawai}

Pada variable pelatihan, didapatkan nilai koefisien sebesar 0,237 yang berarti bahwa apabila rata-rata variable pelatihan naik sebesar 1, maka kinerja pegawai yang dihasilkan akan naik sebesar 0,237. Selain itu nilai signifikansi yang diperoleh sebsar $0,029(\mathrm{p}<0,05)$ yang berarti bahwa pelatihan berpengaruh signifikan terhadap kinerja pegawai PT. Brataco Cabang Surabaya.

Gomes (2013:198) menjelaskan bahwa pelatihan bermanfaat untuk mengatasi kekurangan pengetahuan dan keterampilan yang dimiliki karyawan. Penelitian ini juga mendukung penelitian sebelumnya yang dilakukan oleh Gumilar (2015) bahwa pelatihan berpengaruh signifikan terhadap kemampuan kerja karyawan. Menurut pendapat Mangkunegara (2015), faktor yang dapat mempengaruhi pencapaian kinerja salah satunya adalah faktor kemampuan. Secara lebih jelas, diperkuat dengan teori yang diutarakan oleh Rivai (2015) bahwa kinerja merupakan suatu fungsi dari kemampuan.

Menurut Hasibuan (2017:77) Metode latihan harus berdasarkan kepada kebutuhan pekerjaan tergantung pada berbagai faktor, yaitu waktu, biaya, jumlah peserta, tingkat pendidikan dasar peserta, latar belakang peserta, dan lain-lain. Hal ini berarti bahwa dengan meningkatkan Metode Pelatihan yang baik atau tepat akan meningkatkan pula kinerja karyawan tersebut.

Hal ini juga sejalan dengan penelitian terdahulu yang dilakukan Martha monroza siagian (2010) Pengaruh Pendidikan dan Pelatihan terhadap Kinerja Pegawai Dinas Tenaga Kerja Kota Medan. Menggunakan analisis regresi berganda hubungan antara pendidikan dengan peningkatan kinerja positif dan signifikan pada dinas tenaga kerja kota medan. Dan penelitian yang dilakukan Siagian (2010) Pengaruh Pendidikan dan Pelatihan Terhadap Kinerja Pegawai Dinas dan Sosial dan Tenaga Kerja Kota Medan. Menggunakan analisis regresi berganda hubungan antara pendidikan dengan peningkatan kinerja positif dan signifikan pada pegawai dinas dan sosial dan tenaga kerja kota medan. Juga penelitian yang dilakukan Flavia Da Costa Henriques (2014) Pengaruh Program Pendidikan dan Pelatihan terhadap Kinerja Pegawai (Studi Kasus Pada Instituto Nacional da administração Publica Timor Leste) mengunakan analisis regresi berganda hubungan antara program pendidikan dan pelatihan terhadap kinerja pegawai (studi kasus pada Instituto Nacional Da Administracao Publica Timor Leste) hasil penelitian positif dan signifikan. 


\section{KESIMPULAN DAN SARAN \\ Kesimpulan} berikut:

Kesimpulan yang didapatkan berdasarkan hasil penelitian ini adalah sebagai

1. Karyawan di PT. Brataco Cabang Surabaya memiliki disiplin kerja, etos kerja, pelatihan, dan kinerja yang tinggi.

2. Disiplin kerja berpengaruh terhadap kinerja karyawan di PT. Brataco Cabang Surabaya.

3. Etos kerja berpengaruh terhadap kinerja karyawan di PT. Brataco Cabang Surabaya.

4. Pelatihan berpengaruh terhadap kinerja karyawan di PT. Brataco Cabang Surabaya.

\section{Saran}

Saran yang dapat diberikan berdasarkan hasil penelitian adalah sebagai berikut:

1. Bagi PT. Brataco Cabang Surabaya

Berdasarkan hasil penelitian diketahui bahwa pada variabel disiplin kerja memiliki factor dominan yang mempengaruhi kinerja. Sedangkan nilai terendah pada disiplin kerja yang terletak pada indikator ketepatan waktu, oleh karena itu, pegawai hendaknya menanamkan kesadaran atau kerelaan dirinya sendiri dalam melaksanakan tugas dan bekerja sesuai waktu yang ditentukan yang pada akhirnya dapat mencapai kinerja yang optimal.

2. Bagi Peneliti Selanjutnya

Mengembangkan model penelitian dengan melibatkan variabel kondisional sebagai variabel moderasi.

\section{DAFTAR PUSTAKA}

Anoraga, Panji. 2014. Psikologi Kerja. Jakarta: Penerbit PT. Rineka Cipta.

Sinamo, Jansen. 2011. Etos Kerja Profesional. Jakarta: Institut Dharma Mahardika.

Hasibuan, Malayu S.P.. 2017. Manajemen Sumber Daya Manusia. Edisi Revisi. Jakarta: Bumi Aksara.

Dessler, Gary. 2015. Manajemen Sumber Daya Manusia. Jakarta: Salemba Empat.

Mangkunegara, A.A. Anwar Prabu. 2015. Manajemen Sumber Daya Manusia. Perusahaan, Bandung : Remaja Rosdakarya.

Setiawan, F., \& Kartika Dewi, A. 2014. Pengaruh Kompensasi dan Lingkungan Kerja

Terhadap Kinerja Karyawan Pada CV. Berkat Anugrah. E-Jurnal Manajemen Universitas Udayana, 3 (5)

Simamora, Henry. 2015. Manajemen Sumber Daya Manusia. Yogyakarta: STIEY

Rivai, Veithzal Zainal, S. 2015. Manajemen Sumber Daya Manusia untuk Perusahaan. Edisi ke-7. Depok: PT Rajagrafindo

Siregar, S. 2000. Sumber Daya Manusia (Konsep Universal Etos Kerja). Jakarta: PT. Gramedia.

Khasanah, Uswatun, 2004. Etos Kerja Sarana Menuju Puncak Prestasi. Yogyakarta: Harapan Utama.

Simanjuntak J. Payaman. 2011. Manajemen dan Evaluasi Kinerja, Jakarta: Fakultas. Ekonomi UI. 
Arikunto, S. 2016. Prosedur Penelitian Suatu Pendekatan Praktik. Jakarta: Rineka Cipta.

Sugiyono. 2017. Metode Penelitian Kuantitatif, Kualitatif, dan R\&D. Bandung: Alfabeta

Tasmara, Toto. 2002. Membudayakan Etos Kerja Islami. Jakarta: Gema Insani Press.

Gomes, Faustino Cardoso. 2013. Manajemen Sumber Daya Manusia. Yogyakarta: Andi

Ariana, I Wayan Tresna dan I Gede Riana. 2013. Pengaruh Kepemimpinan, Kompensasi dan Disiplin Kerja Terhadap Kinerja Karyawan Pada Hotel Cendana Resort \& Spa Ubud, Gianyar. E-Jurnal Manajemen Universitas Udayana, 2 (1).

Saleha. 2016. Pengaruh Lingkungan Kerja, Etos Kerja Dan Budaya Kerja Terhadap Kinerja Pegawai Pada Dinas Bina Marga Propinsi Sulawesi Tengah. Jurnal Katalogis Vol. 4, No. 3 (2016)

Gumilar. 2015. Pengaruh Pendidikan Dan Pelatihan Terhadap Kemampuan Dan Kinerja Karyawan (Studi Pada Karyawan PT. Bank NTB Cabang Utama Pejanggik). Jurnal Administrasi Bisnis, Volume 22 Nomor 2

Martha monroza siagian. 2010. Pengaruh Pendidikan dan Pelatihan terhadap Kinerja Pegawai Dinas Tenaga Kerja Kota Medan. Jurnal Fakultas Ilmu Sosial dan Ilmu Politik Universitas Sumatera Utara

Flavia Da Costa Henriques. 2014. Pengaruh Program Pendidikan dan Pelatihan terhadap Kinerja Pegawai (Studi Kasus Pada Instituto Nacional da administração Publica Timor Leste). OJS Vol. 1, No. 1, 2014 